\title{
Grapeleaf Skeletonizer, Harrisina americana (Guerin-Meneville) (Insecta: Lepidoptera: Zygaenidae) ${ }^{1}$
}

\section{F. W. Mead and Susan E. Webb ${ }^{2}$ \\ Introduction}

This species is common throughout Florida, with the possible exception of the Keys, and it ranges widely in the eastern half of the United States. It is noticed primarily because of its defoliation of grapevines in home gardens.

\section{Identification}

Adult moths are uniformly black except for a yellowish or orange collar. The antennae are pectinate in both sexes and plumose in the male. The forewings are four times as long as wide and more than twice the area of the hind wings. The abdomen is usually curled upwards and expanded at the tip into a fan-shaped, somewhat bilobed caudal tuft. Length of the moth is 8 to $12 \mathrm{~mm}$, while the wing expanse is 22 to $28 \mathrm{~mm}$.

Larvae are yellowish and have black spots or bands. They are slightly more than $1 / 2$ inch long when mature.

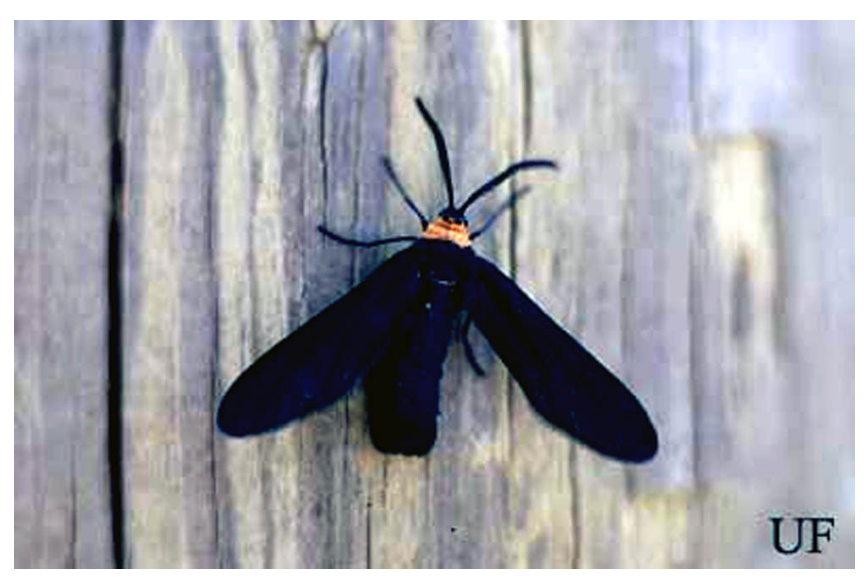

Figure 1. Adult grapeleaf skeletonizer, Harrisina americana (Guérin-Méneville). Credits: Warren Adlerz, University of Florida

Eggs are lemon yellow, cylindrical-oval or capsule-shaped, slightly over $1 / 2 \mathrm{~mm}$ in length, and laid in clusters on lower leaf surfaces.

Similar species in Florida include the zygaenids Acoloithus falsarius Clemens and A. rectarius Dyar. The former is much smaller, the latter slightly smaller than the grapeleaf skeletonizer. Neither species of Acoloithus has the tuft on the tip of the abdomen. Acoloithus falsarius and grapeleaf skeletonizer males

1. This document is EENY-191 (originally published as DPI Entomology Circular 92), one of a series of Featured Creatures from the Entomology and Nematology Department, Florida Cooperative Extension Service, Institute of Food and Agricultural Sciences, University of Florida. Published: February 2001. This document is also available on Featured Creatures Website at http://creatures.ifas.ufl.edu. Please visit the EDIS Website at http://edis.ifas.ufl.edu.

2. F. W. Mead, Florida Department of Agriculture and Consumer Services, Division of Plant Industry and Susan E. Webb, Entomology and Nematology, University of Florida, Gainesville, Florida.

The Institute of Food and Agricultural Sciences (IFAS) is an Equal Employment Opportunity - Affirmative Action Employer authorized to provide research, educational information and other services only to individuals and institutions that function without regard to race, creed, color, religion, age, disability, sex, sexual orientation, marital status, national origin, political opinions or affiliations. For information on obtaining other extension publications, contact your county Cooperative Extension Service office. Florida Cooperative Extension Service / Institute of Food and Agricultural Sciences / University of Florida / Larry R. Arrington, Interim Dean 


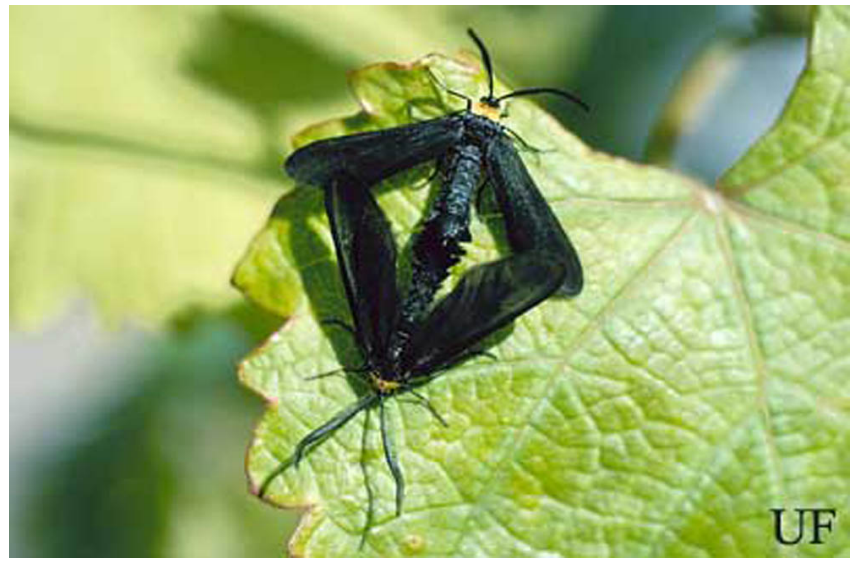

Figure 2. Adult grapeleaf skeletonizers, Harrisina americana (Guérin-Méneville), mating. Credits: Warren Adlerz, University of Florida

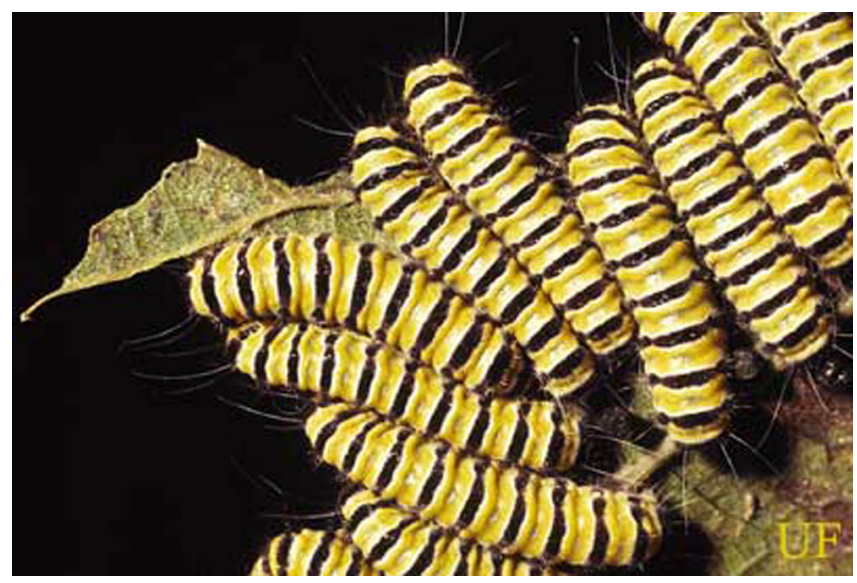

Figure 3. Larvae of the grapeleaf skeletonizer, Harrisina americana (Guérin-Méneville), feeding on a grape leaf. Credits: Warren Adlerz, University of Florida

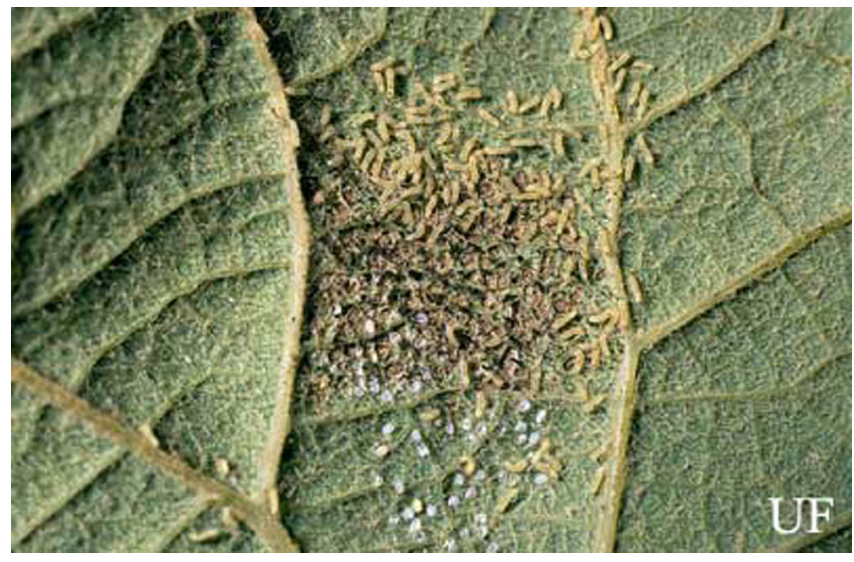

Figure 4. Larvae of the grapeleaf skeletonizer, Harrisina americana (Guérin-Méneville), hatching from an egg cluster on a grape leaf. Credits: Warren Adlerz, University of Flo

respond to the same sex pheromone, but at different times of day. Grapeleaf skeletonizer males are active mostly around dawn and A. falsarius males are more active in the heat of the afternoon (Landolt and Heath 1987). Acoloithus falsarius larvae also feed on grape leaves, especially of wild muscadine grapes, as do the larvae of a closely related species, $A$. novaricus Barnes \& McDunnough (McGiffen and Neunzig 1985). The larvae of the Acoloithus spp. have an off-white or yellow head capsule while skeletonizer larvae have a dark head capsule.

A common species in Florida most likely to be confused with the grapeleaf skeletonizer is the ctenuchid Cisseps fulvicollis (Hübner). Cisseps is slightly larger and thicker bodied, but is similar in its blackish coloration and yellowish collar. The hind wings of Cisseps differ are relatively larger, more triangular, and clear in the middle portion instead of being evenly dark scaled. Cisseps also lacks the tuft on the apex of the abdomen. The western grapeleaf skeletonizer, Harrisina brillians Barnes and McDunnough, is very similar to and slightly larger than $H$. americana, but has not been taken in Florida according to Kimball (1965). H. brillians ranges from California to Texas and south to Mexico.

\section{Life History}

Jones (1909) gives the average length of life cycle as 66.7 days and minimum life cycle as 53 days. He lists the average length of egg stage as nearly eight days, larval stage 40 days, pupal stage 15 days, and length of life of the adult moth as 3.5 days. Kimball (1965) lists moths on the wing in Florida from March to September. Landolt and Heath (1987) caught moths in pheromone traps from late March to mid-October in Gainesville, Florida. The earliest Division of Plant Industry record is February 25 at Homestead, Florida. Winter is passed in the pupal stage. The senior author has seen egg clusters as early as April 7 at Gainesville. Division of Plant Industry records show that larvae have been collected from May to November 14. It seems probable that some larvae appear in April. There are at least two and possibly three (Landolt and Heath 1987) generations per year in Florida. Adults are diurnal and nocturnal.

\section{Damage and Detection}

Initial symptoms include the appearance of brown, necrotic, skeletonized leaf tissue, resulting from young larvae eating some but not all layers of 
the leaf. Later instars devour the leaf, leaving only a few large veins. Larvae attract attention by feeding in groups, usually side by side in a row. This is the only pertinent lepidopterous insect that feeds in a gregarious manner upon grape foliage. As the larvae of the colony become mature they tend to disperse as isolated individuals or in small groups.

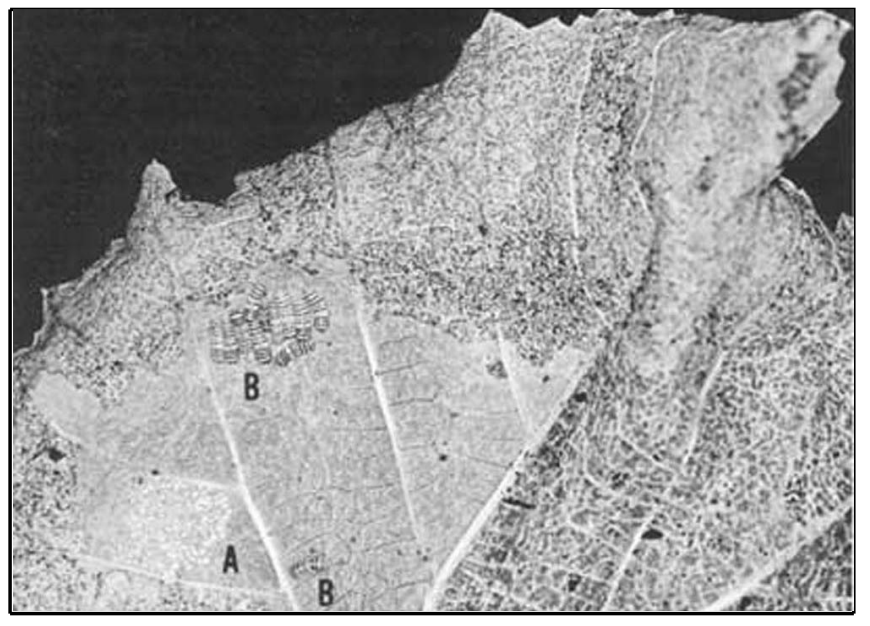

Figure 5.

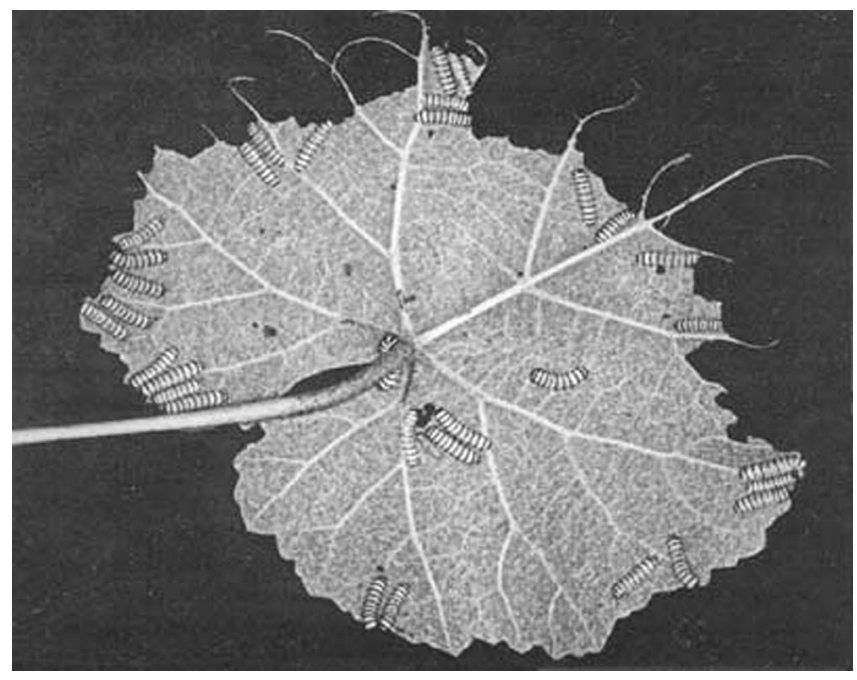

Figure 6. Partial skeletonization of 'Lake Emerald' grape leaf by larvae of the grapeleaf skeletonizers, Harrisina americana (Guérin-Méneville). Credits: Division of Plant Industry

\section{Hosts}

Native hosts include wild grapes and Virginia creeper, Parthenocissus quinquefolia (L.) Planchon. Among cultivated grapes, grapeleaf skeletonizer seems to prefer exotic or the more choice and tender varieties. Adults have been collected in Steiner traps several times.

\section{Management}

Grapeleaf skeletonizer is a minor pest in Florida. Vineyards receiving regular treatment for important grape pests are not troubled with skeletonizers.

Bacillus thuringiensis can be used to control skeletonizer and other caterpillar pests. Handpicking in small areas also is an efficient treatment because of the gregarious feeding habit of the larvae.

Caterpillars should be destroyed as soon as they are noticed on the foliage, as all from each cluster of eggs will be in a single group, whereas if the treatment is delayed until the larvae have separated into individuals or small groups, much more labor will be involved. Since the larvae spin their cocoons in the leaves and trash at the bottom of the vines, clean culture is recommended.

For more information see the Insect Management Guide for Grapes (http://edis.ifas.ufl.edu/IG071).

\section{Selected References}

Jones, P. R. 1909. The grape-leaf skeletonizer. USDA, Bur. of Ent. Bull. 68: 77-90.

Kimball, C. P. 1965. The Lepidoptera of Florida; an annotated checklist. Arthropods of Florida and Neighboring Land Areas Vol. 1. FL. Dep. Agric., Div. Plant Industry. 363 p.

Landolt, P. J. and R. R. Heath. 1987. Seasonal and diel patterns of sex attraction of male Harrisina americana and Acoloithus falsarius (Lepidoptera: Zygaenidae). Fla. Entomol. 70: 392-396.

McGiffen, K. C. and H. H. Neunzig. 1985. A guide to the identification and biology of insects feeding on muscadine and bunch grapes in North Carolina. NC Agric. Res. Serv. Bull. 470. 93 pp. 